\title{
Numerical investigations on vibration characteristics of sandwich plate
}

\author{
Lu Shi, Yining Mao, Ying Chen
}

\author{
Page Number: 57-61
}

\section{This Paper has removed on Authors Request.}

